\title{
PMA-induced up-regulation of MMP-9 is regulated by a PKC $\alpha-N F-k B$ cascade in human lung epithelial cells
}

\author{
YoungHyun $\operatorname{Shin}^{1 *}$, Sun-Hee Yoon ${ }^{1 *}$, \\ Eun-Young Choe ${ }^{1}$, Sung-Hoon Cho ${ }^{1}$, \\ Chang-Hoon Woo ${ }^{1}$, Jee-Yeon Rho ${ }^{1}$ and \\ Jae-Hong $\mathrm{Kim}^{1,2}$ \\ ${ }^{1}$ School of Life Sciences and Biotechnology \\ Korea University \\ Seoul 136-701, Korea \\ ${ }^{2}$ Corresponding author: Tel, 82-2-3290-3452; \\ Fax, 82-2-927-9028; E-mail, jhongkim@korea.ac.kr \\ *These authors contributed equally to this work. \\ Accepted 28 December 2006
}

Abbreviations: DAG, diacylglycerol; ECM, extracellular matrix; MMP, matrix metalloproteinase; PDTC, pyrrolidine dithiocarbamate; PKC, protein kinase $\mathrm{C}$

\begin{abstract}
Expression of matrix metalloproteinase-9 (MMP-9) is associated with airway remodeling and tissue injury in asthma. However, little is known about how MMP-9 is up-regulated in airway epithelial cells. In this study, we show that phorbol myristate acetate (PMA) induces MMP- 9 expression via a protein kinase $C \alpha$ (PKC $\alpha$ )-dependent signaling cascade in BEAS-2B human lung epithelial cells. Pretreatment with either GF109203X, a general PKC inhibitor, or Gö6976, a PKC $\alpha / \beta$ isozyme inhibitor, inhibited PMA-induced activation of the MMP-9 promoter, as did transient transfection with PKC $\alpha$ antisense oligonuclotides. PMA activated NF- $\kappa B$ by phosphorylating $I_{\kappa} B$ in these cells and this was also inhibited by GF109203X and Gö6976, suggesting that $\mathrm{PKC}_{\alpha}$ acts as an upstream regulator of NF-KB in PMA-induced MMP-9 induction. Our results indicate that a "PKC $\alpha-N F-$ $\kappa B$ "-dependent cascade is involved in the signaling leading to PMA-induced MMP-9 expression in the lung epithelium.
\end{abstract}

Keywords: asthma; bronchial hyperreactivity; epithelial cells; matrix metalloproteinase 9 ; NF- $\mathrm{B}$; protein kinase $\mathrm{C}-\alpha$

\section{Introduction}

Airway inflammation, remodeling and hyper-responsiveness are key features of bronchial asthma (Pascual and Peters, 2005). Many inflammatory cells including eosinophils, lymphocytes and mast cells infiltrate from the circulation to specific sites within asthmatic tissue (Hamid et al., 2003). This leads to structural changes in the airway wall involving smooth muscle hypertrophy, subepithelial deposition of ECM proteins and loss of epithelium (Vliagoftis et al., 2000). Although many studies have focused on the key mediators contributing to these structural changes, much of the detailed mechanism is unknown.

The matrix metalloproteinase (MMP) family is a group of structurally-related proteins that degrade ECM and basement membrane in a zinc-dependent manner at physiological $\mathrm{pH}$ (Visse and Nagase, 2003). It comprises at least 26 secreted and membrane-tethered endopeptidases, classified according to their structures and substrate specificities ( $\mathrm{Na}$ gase et al., 2006). Members of the family include: collagenases (MMP-1, -8, -13), gelatinases (MMP-2, $-9)$, stromelysins (MMP-3, -7, -10, -11, -12), and membrane-type-MMPs (MT1-MMP to MT6-MMP). These enzymes have been shown to play key roles in tumor cell invasion, metastasis and angiogenesis by promoting ECM degradation and the processing of cytokines, growth factors, hormones and cell receptors (John and Tuszynski, 2001; Nguyen et al., 2001). MMPs are produced not only by structural cells including fibroblasts, endothelial cells and epithelial cells (Bove et al., 2007) but also by inflammatory cells such as macrophages (Mautino et al., 1997; Lee et al., 2006), lymphocytes (Owen et al., 2003), neutrophils (Delclaux et al., 1996) and eosinophils (Fujisawa et al., 1999). By degrading components of the ECM, MMPs are thought to play a role in tissue remodeling and the accumulation of inflammatory cells associated with asthma (Kelly and Jarjour, 2003). Among the MMP family, MMP-9 is believed to be the major MMP in asthma because its level is increased in the sputum (Vignola et al., 1998) and broncoalveolar lavage (BAL) fluid (Kelly et al., 2000; Atkinson and Senior, 2003; Ohbayashi and Shimokata, 2005) of patients with bronchial asthma.

Previous work has suggested that the induction of MMP-9 is affected by various factors such as proinflammatory cytokines, TGF- $\beta$, EGF, and certain 
oncogenes (Sehgal and Thompson, 1999; Han et al., 2001; Nee et al., 2004; Wu et al., 2004; Chou et al., 2006). Phorbol myristate acetate (PMA), a phorbol ester, is known to substitute for DAG as a high affinity ligand for conventional protein kinase $C$ (PKC) and novel PKC isoforms (Easom et al., 1989). It has been shown to strongly stimulate MMP-9 expression via PKC in several systems (Juarez et al., 1993; Simon et al., 1998; Genersch et al., 2000; Park et al., 2000; 2003). The MMP-9 promoter contains binding sites for transcription factors AP-1, NF-kB, SP1, AP-2 and Ets (PEA3) (Sato and Seiki, 1993; Gum et al., 1996; Chakraborti et al., 2003). Some PKC isoforms activate NF-KB and AP-1 (Dominguez et al., 1993; Lallena et al., 1999), while the atypical PKC isoform $\zeta$ regulates $\mathrm{IKK} \beta$ activity in vitro (Lallena et al., 1999) and $\mathrm{PKC} \varepsilon$ modulates NF- $\mathrm{KB}$ and AP-1 in adult rabbit cardiomyocytes ( $\mathrm{Li}$ et al., 2000). The novel PKC isoform $\theta$ is responsible for NF-kB activation in response to TCR/CD28 costimulation (Coudronniere et al., 2000), and the atypical PKC isoform, $\mathrm{PKC} \zeta$, phosphorylates and inactivates $\mathrm{I}_{\kappa} \mathrm{B} \alpha$ in vitro (Diaz-Meco et al., 1994; Esteve et al., 2002).

Although PKC is important for MMP-9 expression in a number of cell types, little is known about the signaling pathways involved in PKC-mediated MMP9 expression in human lung epithelial cells. In the present study, we focused on the involvement of the different $\mathrm{PKC}$ isoforms in regulating MMP-9 expression in BEAS-2B human bronchial epithelium cells. We report that activation of $\mathrm{PKC} \alpha$ by PMA activates NF-KB and induces MMP-9 expression in these cells.

\section{Materials and Methods}

\section{Chemicals and plasmids}

PMA, gelatin, dimethyl sulfoxide (DMSO) and pyrrolidine dithiocarbamate (PDTC) were purchased from Sigma-Aldrich (St. Louis, MO). Antibodies to MMP-9, $I_{\kappa} B-\alpha$, phospho $I_{\kappa} B-\alpha$, tubulin and various $P K C$ isoforms were from Cell Signaling Technology (Beverly, $M A)$. The following inhibitors were obtained from Calbiochem (La Jolla, CA): GF109203X, a general PKC inhibitor $\left(\mathrm{IC}_{50}=0.2 \mu \mathrm{M}\right)$; Gö6976, a potent inhibitor of $\mathrm{Ca}^{2+}$-dependent PKC isozymes $\left(\mathrm{IC}_{50}=\right.$ $6.2 \mathrm{nM})$; rottlerin, a PKC $\delta$ inhibitor with $\left(\mathrm{IC}_{50}=3-6\right.$ $\mu \mathrm{M})$. The reporter gene pMMP-9-luc containing a 673 bp upstream sequence $(-670 \sim+3)$ of the MMP-9 promoter was a gift from Dr. A.S. Jeong (KAIST, Taejon, Korea). All other chemicals were from standard sources and were of molecular biology grade or higher.

\section{Cell culture}

BEAS-2B human bronchial epithelial cells (American Type Culture Collection, ATCC CRL 9609), were grown in RPMI1640 supplemented with $10 \%$ FBS, $0.1 \mathrm{mM}$ non-essential amino acids, penicillin (50 $\mathrm{U} / \mathrm{ml})$ and streptomycin $(50 \mu \mathrm{g} / \mathrm{ml})$ at $37^{\circ} \mathrm{C}$ in a humidified $95 \% / 5 \%$ (v/v) mixture of air and $\mathrm{CO}_{2}$.

\section{Gelatin zymography}

MMP-9 activity was assayed by gelatin zymography as described previously (Woo et al., 2004). 80\% confluent BEAS-2B cells were incubated in serumfree medium for $6 \mathrm{~h}$ before PMA treatment. After 12 $h$ of PMA stimulation, the culture medium was harvested and stored at $-70^{\circ} \mathrm{C} .40 \mu$ aliquots of thawed culture medium was mixed with non-reducing Laemmli's sample buffer and run on an $8 \%$ SDSPAGE gel containing $0.2 \%$ gelatin. After electrophoresis, the gel was washed three times in $2.5 \%$ Triton X-100 at room temperature for $90 \mathrm{~min}$ to remove SDS, and incubated overnight in a buffer containing $50 \mathrm{mM}$ Tris- $\mathrm{Cl}(\mathrm{pH} 7.6), 150 \mathrm{mM} \mathrm{NaCl}, 5$ $\mathrm{mM} \mathrm{CaCl} 2$ and $200 \mu \mathrm{g} / \mathrm{ml} \mathrm{Brij-} 35$ at $37^{\circ} \mathrm{C}$. It was then stained with Coomassie Brilliant Blue, and gelatinolytic activities were visualized as a clear band against a blue-stained background.

\section{Western blot analysis}

Cells were washed twice with ice-cold PBS, and the whole-cell lysates were obtained using lysis buffer (50 mM Tris-Cl, $150 \mathrm{mM} \mathrm{NaCl}, 0.1 \%$ Triton X-100, $0.02 \% \mathrm{NaN}_{3}, 5 \mathrm{mM}$ EDTA, $1 \mathrm{mM} \mathrm{NaF}, 1 \mathrm{mM}$ PMSF, $1 \mu \mathrm{g} / \mathrm{ml}$ leupeptin and $2 \mu \mathrm{g} / \mathrm{ml}$ pepstatin A). The protein content was quantified using Bradford reagent (Bio-Rad, Hercules, CA), and then $50 \mu \mathrm{g}$ of total protein was subjected to SDS-PAGE on $10 \%$ acrylamide gels, followed by transfer to polyvinylidine difluoride (PVDF) membranes (Amersham Pharmacia Biotech, Ltd, UK) using a wet transfer unit (NOVEX, San Diego CA; for $1 \mathrm{~h}$ at $100 \mathrm{~V}$ ). The membranes were blocked for $1 \mathrm{~h}$ with TBS-T [TBS (150 mM NaCl, 25 mM Tris- $\mathrm{Cl}, \mathrm{pH} 7.4$ ) with $0.05 \%$ Tween-20] containing $5 \%(\mathrm{w} / \mathrm{v})$ nonfat dry milk, washed three times with TBS-T for 5 min each, and then incubated with primary antibody in TBS-T containing $2 \%(\mathrm{w} / \mathrm{v})$ nonfat dry milk overnight at $4{ }^{\circ} \mathrm{C}$, and then with HRP-conjugated secondary anti-rabbit antibody for $1 \mathrm{~h}$. The bands were developed using enhanced chemiluminescence (ECL) detection system (Amersham Pharmacia Biotech, Ltd, UK).

\section{Transient transfection and luciferase assay}

BEAS-2B cells were seeded in $35 \mathrm{~mm}$ dishes at a concentration of $10^{5}$ cells per dish $24 \mathrm{~h}$ prior to 
transfection. The pMMP-9-Luc reporter was introduced into the cells using Lipofectamine-Plus (Invitrogen, Calsbad, CA). Transfection efficiencies were normalized by co-transfection with $0.4 \mu \mathrm{g}$ of pSV$\beta G A L$, a eukaryotic expression vector containing the $E$. coli $\beta$-galactosidase (lac Z) structural gene under the control of the SV40 promoter. The cells were incubated with the DNA mixture for $3 \mathrm{~h}$ following which the culture medium was changed to complete RPMI 1640 medium. $24 \mathrm{~h}$ after transfection, the cells were preincubated (where desired) with inhibitors for 30 min prior to stimulation with PMA for $6 \mathrm{~h}$, and then lysed in $0.15 \mathrm{ml}$ of lysis solution $(0.2 \mathrm{M}$ Tris $\mathrm{pH}$ $7.6,0.1 \%$ Triton $\mathrm{X}-100)$. The resulting extracts were spun for $5 \mathrm{~min}$ and the supernatants were assayed for protein and $\beta$-galactosidase activity. Luciferase

\section{A}

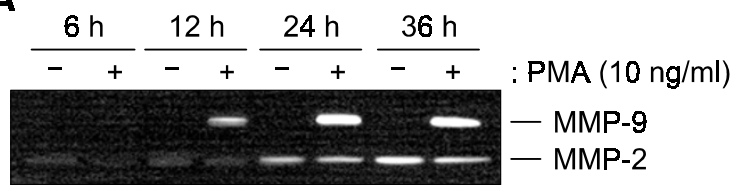

B
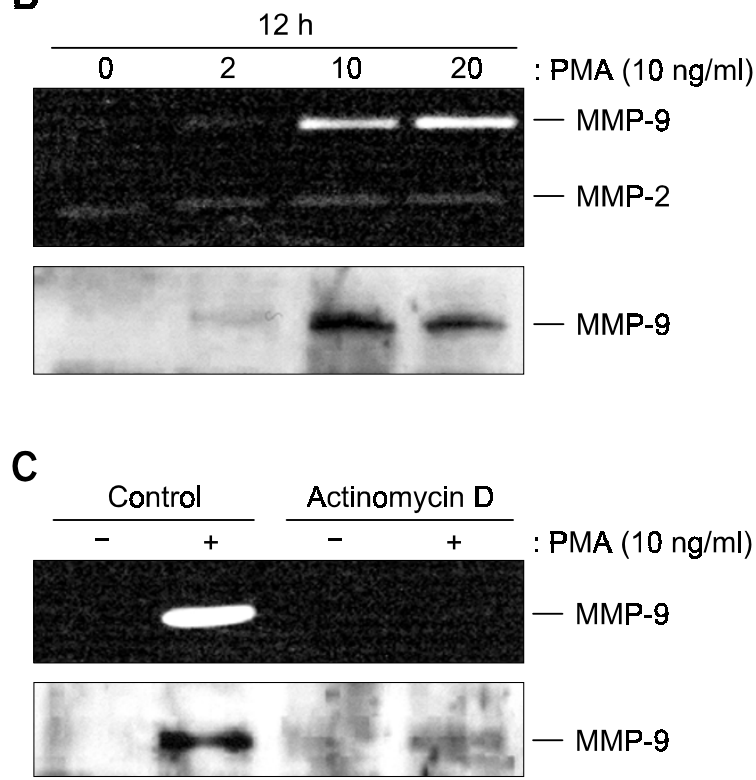

activity was assayed in $10 \mu \mathrm{l}$ samples of extract and luciferase luminescence was measured in a Turner TD 20/20 luminometer (Turner Designs, Sunnyrale, CA) and normalized with the co-transfected $\beta$-galactosidase activity, as described (Yoo et al., 2001). Transfection experiments were performed in triplicate with two independently isolated sets of cells and the results were averaged.

Transfection with antisense PKC $\alpha$ oligonucleotides Phosphorothioate derivatives of antisense and sense oligonucleotides of PKC $\alpha$ were designed against the translation start site of the PKC $\alpha$ isoform (Shih et al., 1999) and obtained from GenoTech (Taejon, Korea). For transient transfection with the antisense oligonucleotides, about $1 \times 10^{5}$ BEAS-2B cells were plated in $35 \mathrm{~mm}$ dishes for $24 \mathrm{~h}$. The Lipofectamine Plus/DNA complex was then added and after $3 \mathrm{~h}$ incubation the cells were rinsed with PBS and incubated for $24 \mathrm{~h}$ in fresh RPMI 1640 supplemented with $10 \%$ FBS.

\section{Results}

PMA induces MMP-9 expression in BEAS-2B cells We first examined the effect of PMA on MMP-9 activity in BEAS-2B cells. After starvation in serum-free RPMI 1640 for $6 \mathrm{~h}$ the cells were stimulated

\section{D}

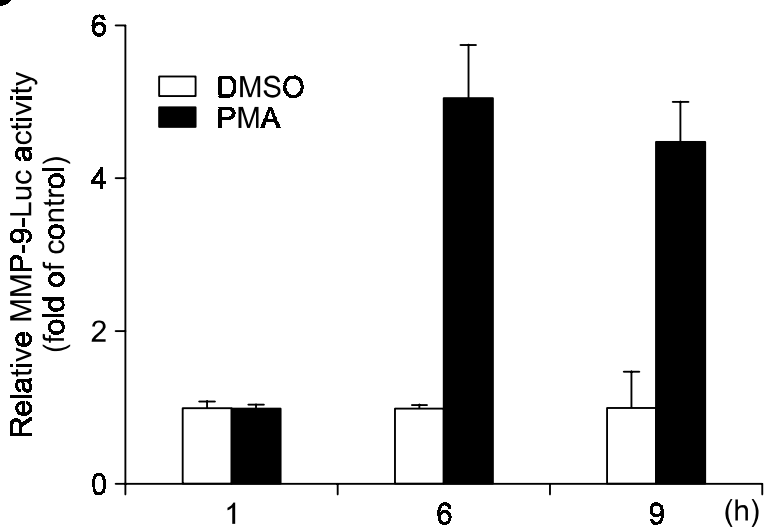

Figure 1. PMA induces MMP-9 expression in BEAS-2B cells. (A) Time-dependent activation of MMP-9 by PMA. BEAS-2B cells were grown for the indicated periods in serum-free medium alone or with PMA $(10 \mathrm{ng} / \mathrm{ml})$. Conditioned media were subjected to $8 \%$ SDS-PAGE with $0.2 \%$ gelatin and the gelatinolytic activities of MMP-9 and MMP-2 were determined by zymography as described in Materials and Methods. (B) Concentration-dependent induction of MMP-9 by PMA. BEAS-2B cells were grown with the indicated concentrations of PMA for $12 \mathrm{~h}$. Conditioned media and whole cell lysates were analyzed for MMP-9 and MMP-2 activity as before (upper panel), and for MMP-9 expression by Western blotting (lower panel). (C) Inhibition of PMA-induced MMP-9 induction by actinomycin D. BEAS-2B cells were pretreated with actinomycin D $(2 \mu \mathrm{g} / \mathrm{ml})$ for 30 min before challenge with PMA $(10 \mathrm{ng} / \mathrm{ml})$ for $12 \mathrm{~h}$ and the gelatinolytic activity and expression of MMP-9 were assayed by zymography (upper panel) and Western blotting (lower panel), respectively. (D) PMA induces MMP-9 promoter activity. BEAS-2B cells were transfected with an MMP-9-responsive luciferase reporter gene (pMMP-9-Luc). The transfectants were incubated with DMSO or PMA (10 ng/ml) for the indicated times, and their relative luciferase activities were measured. Bars depict the means $\pm S D$ of three independent experiments, and the data are expressed as fold increases relative to the control value. 
with PMA (10 ng/ml) and conditioned media were collected at successive times point. MMP-9 activity was found to increase progressively up to $24 \mathrm{~h}$ (Figure 1A) while MMP-2 activity did not greatly change. The optimal concentration of PMA was $10-20 \mathrm{ng} / \mathrm{ml}$ (Figure 1B). To see whether MMP-9 expression is regulated transcriptionally, we examined the effect of the transcription inhibitor, actinomycin D, on MMP-9 expression. When the BEAS$2 B$ cells were incubated with actinomycin $D(2 \mu \mathrm{g} /$ $\mathrm{ml}$ ), PMA-induced MMP-9 expression was dramatically reduced (Figure $1 \mathrm{C}$ ). We also examined activation of the MMP-9 promoter by means of luciferase reporter gene assays and found that PMA stimulation ( $6 \mathrm{~h}$ and $9 \mathrm{~h}$ ) increased promoter activity

A

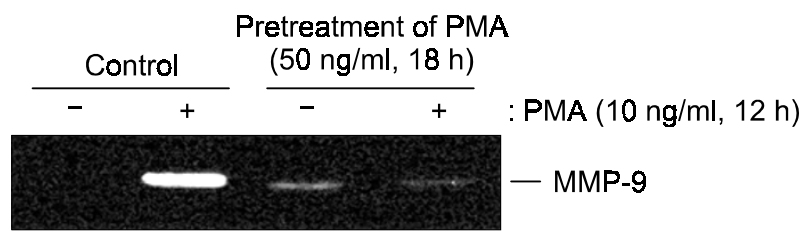

B
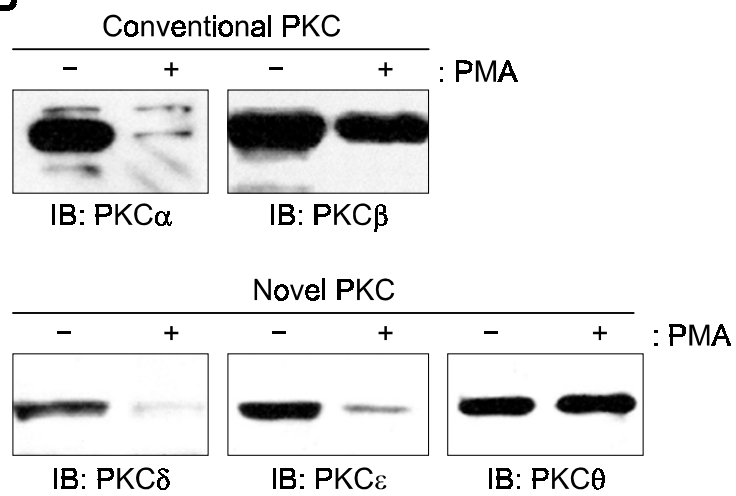

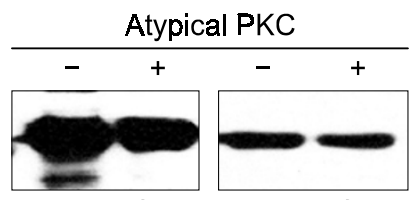

IB: $\mathrm{PKC}_{1}$

IB: $\mathrm{PKC} \lambda$

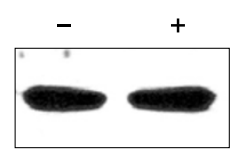

IB: tubulin : PMA

C

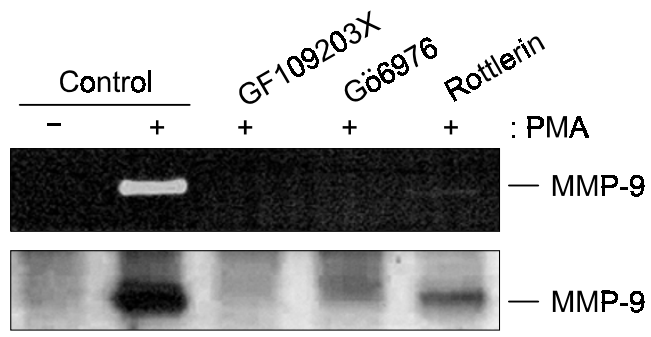

about 5-fold. These results indicate that PMA induces MMP-9 expression at the transcriptional level (Figure 1D).

\section{PMA-induced MMP-9 up-regulation is mediated by a PKC-dependent cascade}

Phorbol esters such as PMA activate PKC by serving as hydrophobic anchors to recruit PKC to the membrane. Prolonged stimulation with phorbol esters results in down-regulation of some $\mathrm{PKC}$ isoforms (Yaney et al., 2002). When BEAS-2B cells were pre-incubated with PMA $(50 \mathrm{ng} / \mathrm{ml})$ for $18 \mathrm{~h}$ and then stimulated with PMA, MMP-9 induction was significantly reduced (Figure $2 A$ ). To identify the PKC

Figure 2. PKC is involved in PMA-induced MMP-9 up-regulation. (A) BEAS-2B cells were pretreated with PMA (50 $\mathrm{ng} / \mathrm{ml}$ ) for $18 \mathrm{~h}$ and the culture medium was replaced to remove the PMA. After $12 \mathrm{~h}$, the cells were re-stimulated with PMA (10 ng/ml) and the gelatinolytic activity of MMP-9 was measured. (B) BEAS-2B cells were exposed to DMSO or PMA $(50 \mathrm{ng} / \mathrm{ml})$ for $18 \mathrm{~h}$ and whole cell lysates were analyzed for down-regulation of PKC isoforms by Western blotting using antibodies against specific PKC isoforms. The blot was also probed with anti-tubulin antibody as a loading control. (C) BEAS-2B cells were pretreated with control buffer, GF109203X (100 nM), Gö6976 (100 nM) or rottlerin $(5 \mu \mathrm{M})$ for 30 min before challenge with PMA (10 ng/ml) for $12 \mathrm{~h}$. The activity of MMP-9 was analyzed (upper panel) and MMP-9 expression was measured by Western blotting (lower panel). (D) After transfection with the pMMP-9-Luc reporter plasmid, cells were pretreated with buffer, GF109203X (100 nM), Gö6976 (100 nM) or rottlerin (5 $\mu \mathrm{M})$ for $30 \mathrm{~min}$ before challenge with PMA $(10 \mathrm{ng} / \mathrm{ml})$ for $12 \mathrm{hr}$, and their relative luciferase activities were measured. Bars depict the means \pm SD of three independent experiments, and the data are expressed as fold increases relative to the control value. 
isoforms involved in MMP-9 induction we examined the levels of different PKC isoforms after prolonged $(18 \mathrm{~h})$ PMA treatment and found that PMA selectively down regulated $\mathrm{PKC} \alpha, \delta$, and $\varepsilon$ while not affecting $\mathrm{PKC} \beta, \theta, \mathbf{\imath}$, and $\lambda$ (Figure 2B). Zymography and Western blotting analysis revealed that MMP-9 expression in response to PMA was markedly decreased by the general PKC inhibitor (GF109203X, $100 \mathrm{nM}$ ) and the conventional PKC inhibitor Gö6976 (100 nM) (Figure 2C), and the same was true of MMP-9 promoter activity (Figure 2D). However, the PKC $\delta$ specific inhibitor, rottlerin, only partially suppressed MMP-9 induction. These results suggest that activation of a conventional PKC, probably PKC $\alpha$, plays an important role in regulating MMP-9 activity in these cells.

\section{PKC $\alpha$ and NF-KB are involved in the PMA-induced MMP-9 expression}

To investigate the role of $\mathrm{PKC} \alpha$ in MMP-9 expression in the BEAS-2B cells, we transfected the cells with $\mathrm{PKC} \alpha$ antisense oligonucleotides and noted that MMP-9 secretion in response to PMA was greatly reduced (Figure $3 A$ ). A similar result was obtained in MMP-9 promoter assays (Figure 3B). The MMP-9 promoter contains binding sites for the transcription factors AP-1, NF- $\mathrm{B}, \mathrm{SP} 1, \mathrm{AP}-2$ and Ets (PEA3) (Chakraborti et al., 2003), and PKC isoforms have been reported to activate NF-kB and AP-1 (Dominguez et al., 1993; Lallena et al., 1999; Chakraborti et al., 2003). To determine which transcription factor(s) are involved in PMA-induced MMP-9 expression, we transiently transfected BEAS-2B cells with NF-кB-luciferase or AP-1-luciferase plasmids, and stimulated them with PMA $(10 \mathrm{ng} / \mathrm{ml})$. PMA significantly activated $N F-\kappa B$, but not $A P-1$ (data not shown). To see whether the NF-кB activation is related to PMA-induced MMP-9 expression, we tested the effects of the NF- $\kappa B$ inhibitor, pyrrolidine dithio carbamate (PDTC), on MMP-9 promoter activity. Pretreating BEAS-2B cells for 30 min with the NF- $\kappa B$ inhibitor, PDTC $(50 \mu \mathrm{M})$ dramatically reduced PMA-induced MMP-9 promoter activation (Figure 4A), and lowered PMA-induced MMP-9 activity in a dose-dependent manner (Figure $4 \mathrm{~B}$, upper panel). Heterodimers of NF- $\mathrm{KB}$ consist of p50 and p65 subunits and exists in the cytoplasm in inactive form bound to the inhibitory protein $I_{\kappa} B$ through p65 (Ghosh and Karin, 2002; Luo et al., 2004). Phosphorylation of $I_{\kappa} B$ and its subsequent degradation are critical steps in NF- $\mathrm{B}$ activation. We found that PMA induced both phosphorylation and degradation of $I_{\kappa} B-\alpha$ in BEAS-2B cells within several minutes (Figure $4 B$, lower panel). We conclude that PMA-induced $N F-\kappa B$ activation results from phosphorylation and degradation of $I_{\kappa} B-\alpha$ and that the induction of MMP-9 is due to this NF- $\kappa B$ activation. To investigate whether $P K C \alpha$ is the upstream regulator of $N F-\kappa B$ activation during PMAinduced MMP-9 production, we examined the effect of the PKC $\alpha$ inhibitors on PMA-induced phosphorylation and degradation of $1 \kappa \mathrm{B} \alpha$. Western blotting revealed that NF- $\mathrm{KB}$ activation was markedly reduced by GF109203X and Gö6976, suggesting that a $\mathrm{PKC} \alpha-N F-\kappa B$ cascade is responsible for PMAinduced MMP-9 production (Figure $4 \mathrm{C}$ ).
A
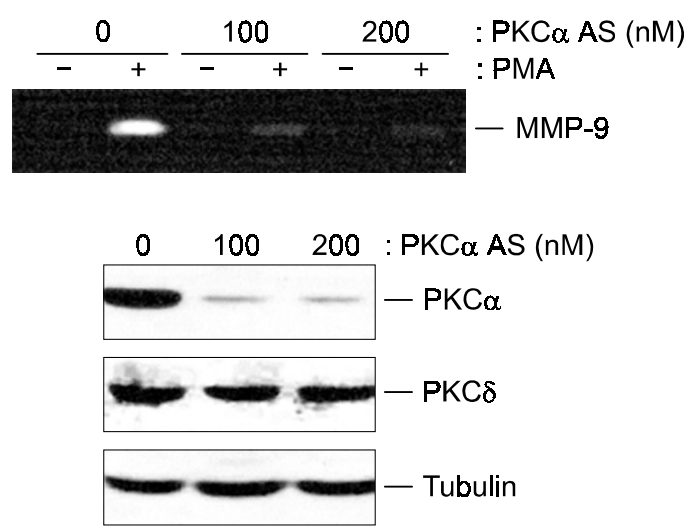

B

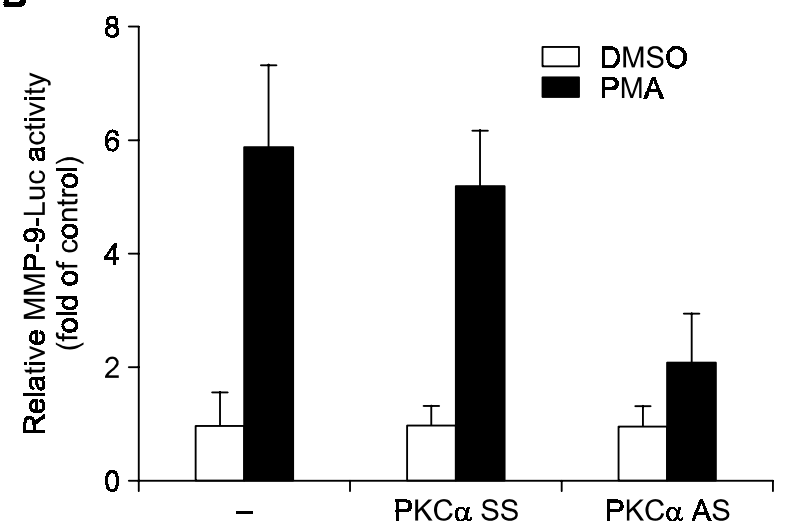

Figure 3. PKC $\alpha$ mediates PMA-induced MMP-9 up-regulation in BEAS-2B cells. (A) BEAS-2B cells were transfected with antisense PKC $\alpha$ oligonucleotides (PKC $\propto$ AS) and transfectants and control cells were incubated for $12 \mathrm{~h}$ in the presence or absence of PMA (10 ng/ml). The conditioned media were assayed for gelatinolytic activity (upper panel) and whole cell lysates were analyzed for PKC $\alpha$ by Western blotting (lower panels). (B) BEAS-2B cells were co-tranfected with the pMMP-9-Luc reporter plasmid and antisense or sense PKC $\alpha$ oligonucleotides (PKC $\alpha$ SS), incubated with DMSO or PMA $(10 \mathrm{ng} / \mathrm{ml})$ for $6 \mathrm{~h}$, and their relative luciferase activities were determined. Bars depict the means \pm SD of three independent experiments, and the data are expressed as fold increases relative to the control. 


\section{Discussion}

In this study we investigated the signaling pathways leading to the production of MMP-9 in BEAS-2B human bronchial epithelial cells. Our results demonstrate that a 'PKC $\alpha-N F-\kappa B$ '-cascade is responsible for the up-regulation of MMP-9 in response to PMA.

MMPs are a family of proteases that are important in turnover of the extracellular matrix and in cell migration (Naito and Yoshikawa, 2005). Increased production of MMP-9 from infiltrating immune cells or from the respiratory epithelium occurs in inflamma-

A

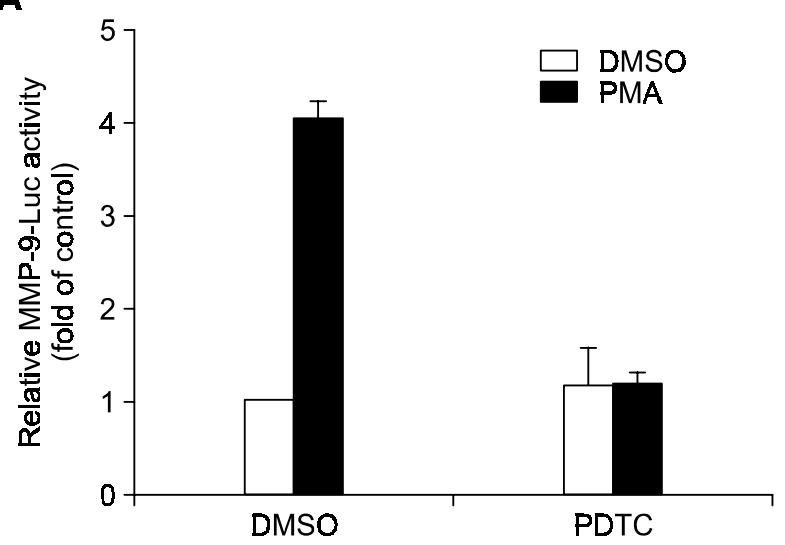

B
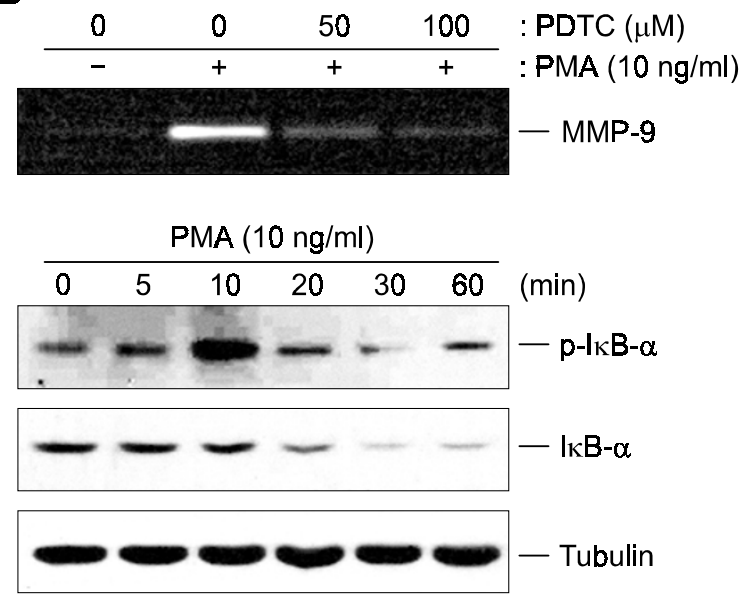

tory lung diseases, and abnormal expression and activation of MMP-9 tend to accompany tissue injury and airway remodeling (Okamoto et al., 2002; Kim et al., 2004; Dik et al., 2005). Cataldo et al. showed that deletion of the MMP-9 gene reduces peribronchial inflammation, airway lymphocyte accumulation, airway IL-13 production and the development of bronchial hyperresponsiveness (2002). The detailed mechanisms controlling MMP-9 activation in the airway microenvironment during the development of asthma remain to be determined, but there could be cross-talk between the epithelium and inflammatory cells.

Our data are compatible with the recent observations that up-regulation of PKC $\alpha$ induces secretion of MMP-9 in capillary endothelial cells (Park et al., 2003), that the PKC-dependent NF-KB activation is absolute for MMP-9 induction in hepatocellular carcinoma cells (Hah and Lee, 2003), and that inhibition of NF-kB activity by synthetic compounds inhibits MMP-9 secretion (Ko et al., 2005). Different isoforms of PKC has been implicated in MMP-9 expression in various cell types. For example, PKC $\zeta$ was shown to be involved in the regulation of MMP-9 expression in C6 glioma cells (Esteve et al., 2002); $\mathrm{PKC} \delta$ was involved in TPA-induced MMP-9 expression in breast cancer MCF-7 cells (Liu et al., 2002); and $\mathrm{PKC} \beta$ was involved in PMA-induced MMP-9 gene expression in human HL-60 myeloid leukemia cells (Xie et al., 1998).

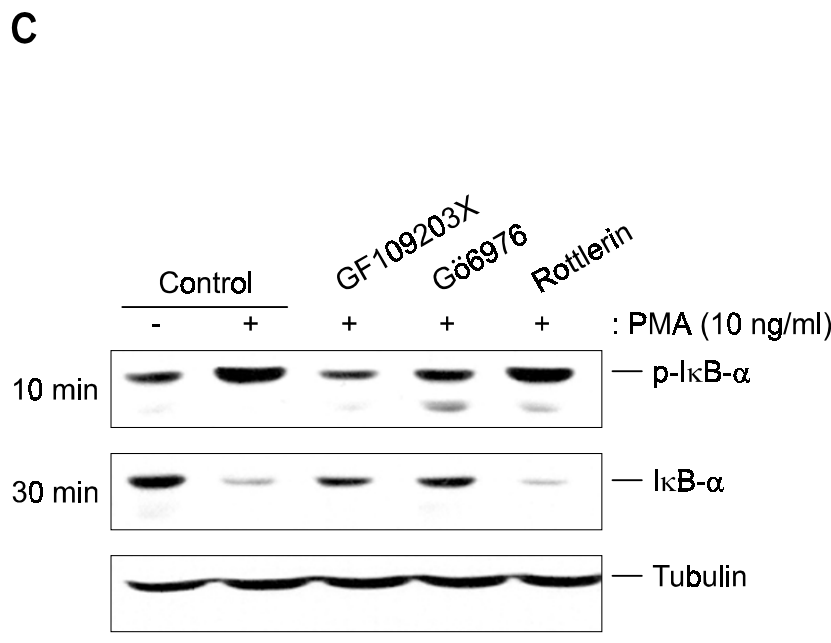

Figure 4. PMA induces NF-KB-dependent up-regulation of MMP-9 in BEAS-2B cells. (A) BEAS-2B cells were transfected with the pMMP-9-Luc reporter plasmid. The transfected cells were incubated with DMSO or PMA $(10 \mathrm{ng} / \mathrm{ml})$ in the presence or absence of PDTC (100 $\mu \mathrm{M})$, an NF-kB inhibitor, and their relative luciferase activities were measured. Bars depict the means \pm SD of three independent experiments, and the data are expressed as fold increases relative to the control value. (B) BEAS-2B cells were pretreated with the indicated concentrations of PDTC for 30 min and exposed to PMA (10 ng/ml) for $12 \mathrm{~h}$. MMP-9 activity was determined by zymography (upper panel). In addition BEAS-2B cells were exposed to PMA $(10 \mathrm{ng} / \mathrm{ml})$ for the indicated times and phosphorylation and degradation of $I_{\kappa} B-\alpha$ were analyzed by Western blotting (lower panels). The results shown are representative of three independent experiments. (C) BEAS-2B cells were pretreated with buffer, GF109203X (100 nM), G0̈6976 (100 nM) or rottlerin $(5 \mu \mathrm{M})$ for $30 \mathrm{~min}$ and then exposed to PMA $(10 \mathrm{ng} / \mathrm{ml})$ for the indicated times. Phosphorylation and degradation of $I_{\kappa} B-\alpha$ were analyzed by Western blotting. The results shown are representative of three independent experiments. 


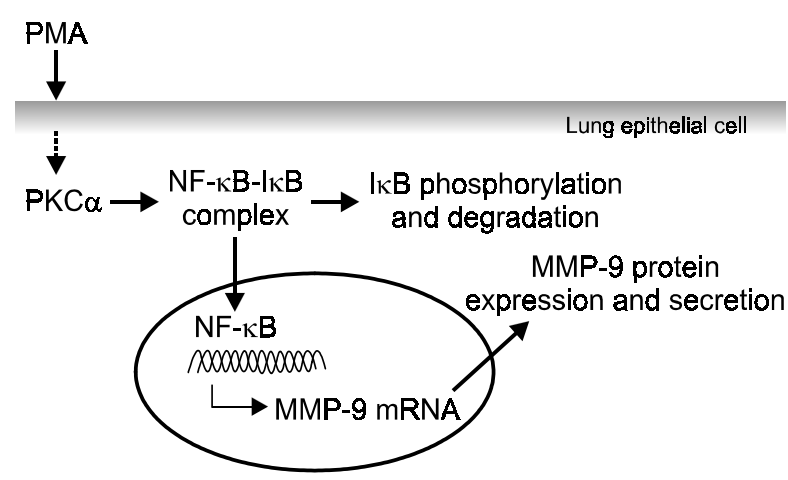

Figure 5. Schematic model of MMP-9 induction by PMA. PMA triggers activation of $P K C \alpha$ which then activates NF-kB as a result of the phosphorylation and subsequent degradation of $I_{\kappa} \mathrm{B}-\alpha$ which binds to NF- $\kappa B$ and anchors it in the cytoplasm. The freed NF- $\kappa B$ translocates to the nucleus and induces MMP-9 transcription.

Although further studies are needed to examine the possible roles of $\mathrm{PKC} \delta$ and $\mathrm{PKC} \varepsilon$ in MMP-9 regulation, we have shown that at least a PKC $\alpha-N F-$ $\kappa \mathrm{B}$-linked cascade is important in the case of human lung epithelial cells, as summarized in the schematic model in Figure 5. We therefore suggest that PKC $\alpha$ inhibitors could be effective therapeutic agents against airway remodeling-related diseases such as asthma.

\section{Acknowledgement}

This work was supported by grants from the SRC program (Aging and Apoptosis Research Center) from the Korea Science and Engineering Foundation (KOSEF), a Molecular and Cellular BioDiscovery Research Program grant (M10311000003-03B4500-00100), and a Frontier 21 Program (Proteomics; M102KM010001-02K1301-005) from the Ministry of Science and Technology, Korea. It was also partially supported by a grant of the Korea Health $21 \mathrm{R} \& \mathrm{D}$ Project (A040004), Ministry of Health and Welfare, Korea.

\section{References}

Atkinson JJ, Senior RM. Matrix metalloproteinase-9 in lung remodeling. Am J Respir Cell Mol Biol 2003;28:12-24

Bove PF, Wesley UV, Greul AK, Hristova M, Dostmann WR, van der Vliet A. Nitric oxide promotes airway epithelial wound repair through enhanced activation of MMP-9. Am J Respir Cell Mol Biol 2007;36:138-46

Cataldo DD, Tournoy KG, Vermaelen K, Munaut C, Foidart JM, Louis R, Noel A, Pauwels RA. Matrix metalloproteinase-9 deficiency impairs cellular infiltration and bronchial hyperresponsiveness during allergen-induced airway inflammation. Am J Pathol 2002;161:491-8

Chakraborti S, Mandal M, Das S, Mandal A, Chakraborti T.
Regulation of matrix metalloproteinases: an overview. Mol Cell Biochem 2003;253:269-85

Chou YT, Wang H, Chen Y, Danielpour D, Yang YC. Cited2 modulates TGF-beta-mediated upregulation of MMP9. Oncogene 2006;25:5547-60

Coudronniere N, Villalba M, Englund N, Altman A. NF-kappa $B$ activation induced by $T$ cell receptor/CD28 costimulation is mediated by protein kinase C-theta. Proc Natl Acad Sci USA 2000;97:3394-9

Delclaux C, Delacourt C, D'Ortho MP, Boyer V, Lafuma C, Harf A. Role of gelatinase $B$ and elastase in human polymorphonuclear neutrophil migration across basement membrane. Am J Respir Cell Mol Biol 1996;14:288-95

Diaz-Meco MT, Dominguez I, Sanz L, Dent P, Lozano J, Municio MM, Berra E, Hay RT, Sturgill TW, Moscat J. zeta PKC induces phosphorylation and inactivation of I kappa B-alpha in vitro. Embo J 1994;13:2842-8

Dik WA, van Kaam AH, Dekker T, Naber BA, Janssen DJ, Kroon AA, Zimmermann LJ, Versnel MA, Lutter R. Early increased levels of matrix metalloproteinase- 9 in neonates recovering from respiratory distress syndrome. Biol Neonate 2005;89:6-14

Dominguez I, Sanz L, Arenzana-Seisdedos F, Diaz-Meco MT, Virelizier JL, Moscat J. Inhibition of protein kinase C zeta subspecies blocks the activation of an NF-kappa B-like activity in Xenopus laevis oocytes. Mol Cell Biol 1993;13:1290-5

Easom RA, Hughes JH, Landt M, Wolf BA, Turk J, McDaniel ML. Comparison of effects of phorbol esters and glucose on protein kinase $\mathrm{C}$ activation and insulin secretion in pancreatic islets. Biochem J 1989;264:27-33

Esteve PO, Chicoine E, Robledo O, Aoudjit F, Descoteaux A, Potworowski EF, St-Pierre Y. Protein kinase $C$-zeta regulates transcription of the matrix metalloproteinase- 9 gene induced by IL-1 and TNF-alpha in glioma cells via NF-kappa B. J Biol Chem 2002;277:35150-5

Fujisawa T, Kato Y, Terada A, Iguchi K, Kamiya H. Matrix metalloproteinase-9 in peripheral blood eosinophils. Int Arch Allergy Immunol 1999;120:65-9

Genersch E, Hayess K, Neuenfeld Y, Haller H. Sustained ERK phosphorylation is necessary but not sufficient for MMP-9 regulation in endothelial cells: involvement of Ras-dependent and -independent pathways. J Cell Sci 2000;113:4319-30

Ghosh S, Karin M. Missing pieces in the NF-kappaB puzzle. Cell 2002;109:81-96

Gum R, Lengyel E, Juarez J, Chen JH, Sato H, Seiki M, Boyd $D$. Stimulation of $92-\mathrm{kDa}$ gelatinase $B$ promoter activity by ras is mitogen-activated protein kinase kinase 1-independent and requires multiple transcription factor binding sites including closely spaced PEA3/ets and AP-1 sequences. J Biol Chem 1996;271:10672-80

Hah N, Lee ST. An absolute role of the PKC-dependent NF-kappaB activation for induction of MMP-9 in hepatocellular carcinoma cells. Biochem Biophys Res Commun 2003;305: 428-33

Hamid Q, Tulic MK, Liu MC, Moqbel R. Inflammatory cells in 
asthma: mechanisms and implications for therapy. J Allergy Clin Immunol 2003;111:S5-S12

Han YP, Tuan TL, Hughes M, Wu H, Garner WL. Transforming growth factor-beta- and tumor necrosis factor-alpha-mediated induction and proteolytic activation of MMP-9 in human skin. J Biol Chem 2001;276:22341-50

John A, Tuszynski G. The role of matrix metalloproteinases in tumor angiogenesis and tumor metastasis. Pathol Oncol Res $2001 ; 7: 14-23$

Juarez J, Clayman G, Nakajima M, Tanabe KK, Saya H, Nicolson GL, Boyd D. Role and regulation of expression of 92-kDa type-IV collagenase (MMP-9) in 2 invasive squamous-cell-carcinoma cell lines of the oral cavity. Int $\mathrm{J}$ Cancer 1993;55:10-8

Kelly EA, Busse WW, Jarjour NN. Increased matrix metalloproteinase- 9 in the airway after allergen challenge. Am J Respir Crit Care Med 2000;162:1157-61

Kelly EA, Jarjour NN. Role of matrix metalloproteinases in asthma. Curr Opin Pulm Med 2003;9:28-33

Kim JH, Lee SY, Bak SM, Suh IB, Lee SY, Shin C, Shim JJ, In KH, Kang KH, Yoo SH. Effects of matrix metalloproteinase inhibitor on LPS-induced goblet cell metaplasia. Am J Physiol Lung Cell Mol Physiol 2004;287:L127-33

Ko HM, Park YM, Jung B, Kim HA, Choi JH, Park SJ, Lee HK, Im SY. Involvement of matrix metalloproteinase-9 in platelet-activating factor-induced angiogenesis. FEBS Lett 2005; 579:2369-75

Lallena MJ, Diaz-Meco MT, Bren G, Paya CV, Moscat J. Activation of lkappaB kinase beta by protein kinase $\mathrm{C}$ isoforms. Mol Cell Biol 1999;19:2180-8

Lee KJ, Kim YM, Kim DY, Jeoung D, Han K, Lee ST, Lee YS, Park KH, Park JH, Kim DJ, Hahn JH. Release of heat shock protein 70 (Hsp70) and the effects of extracellular Hsp70 on matric metalloproteinase- 9 expression in human monocytic U937 cells. Exp Mol Med 2006;38:364-74

Li RC, Ping P, Zhang J, Wead WB, Cao X, Gao J, Zheng Y, Huang S, Han J, Bolli R. PKCepsilon modulates NF-kappaB and $A P-1$ via mitogen-activated protein kinases in adult rabbit cardiomyocytes. Am J Physiol Heart Circ Physiol 2000;279: H1679-89

Liu JF, Crepin, M, Liu JM, Barritault D, Ledoux D. FGF-2 and TPA induce matrix metalloproteinase-9 secretion in MCF-7 cells through PKC activation of the Ras/ERK pathway. Biochem Biophys Res Commun 2002;293:1174-82

Luo JL, Maeda S, Hsu LC, Yagita H, Karin M. Inhibition of NF-kappaB in cancer cells converts inflammation-induced tumor growth mediated by TNFalpha to TRAIL-mediated tumor regression. Cancer Cell 2004;6:297-305

Mautino G, Oliver N, Chanez P, Bousquet J, Capony F. Increased release of matrix metalloproteinase-9 in bronchoalveolar lavage fluid and by alveolar macrophages of asthmatics. Am J Respir Cell Mol Biol 1997;17:583-91

Nagase $H$, Visse R, Murphy $G$. Structure and function of matrix metalloproteinases and TIMPs. Cardiovasc Res 2006;69: 562-73
Naito Y, Yoshikawa T. Role of matrix metalloproteinases in inflammatory bowel disease. Mol Aspects Med 2005;26: 379-90

Nee LE, McMorrow T, Campbell E, Slattery C, Ryan MP. TNF-alpha and IL-1 beta-mediated regulation of MMP-9 and TIMP-1 in renal proximal tubular cells. Kidney Int 2004;66: 1376-86

Nguyen M, Arkell J, Jackson CJ. Human endothelial gelatinases and angiogenesis. Int J Biochem Cell Biol 2001;33: 960-70

Ohbayashi $\mathrm{H}$, Shimokata K. Matrix metalloproteinase-9 and airway remodeling in asthma. Curr Drug Targets Inflamm Allergy 2005;4:177-81

Okamoto T, Valacchi G, Gohil K, Akaike T, van der Vliet A. S-nitrosothiols inhibit cytokine-mediated induction of matrix metalloproteinase-9 in airway epithelial cells. Am J Respir Cell Mol Biol 2002;27:463-73

Owen JL, Iragavarapu-Charyulu V, Gunja-Smith Z, Herbert LM, Grosso JF, Lopez DM. Up-regulation of matrix metalloproteinase-9 in T lymphocytes of mammary tumor bearers: role of vascular endothelial growth factor. J Immunol 2003; 171:4340-51

Park MJ, Park IC, Hur JH, Rhee CH, Choe TB, Yi DH, Hong $\mathrm{SI}$, Lee $\mathrm{SH}$. Protein kinase $\mathrm{C}$ activation by phorbol ester increases in vitro invasion through regulation of matrix metalloproteinases/tissue inhibitors of metalloproteinases system in D54 human glioblastoma cells. Neurosci Lett 2000; 290:201-4

Park MJ, Park IC, Lee HC, Woo SH, Lee JY, Hong YJ, Rhee $\mathrm{CH}$, Lee YS, Lee SH, Shim BS, Kuroki T, Hong SI. Protein kinase $\mathrm{C}$-alpha activation by phorbol ester induces secretion of gelatinase B/MMP-9 through ERK $1 / 2$ pathway in capillary endothelial cells. Int J Oncol 2003;22:137-43

Pascual RM, Peters SP. Airway remodeling contributes to the progressive loss of lung function in asthma: an overview. J Allergy Clin Immunol 2005;116:477-86

Sato $\mathrm{H}$, Seiki M. Regulatory mechanism of $92 \mathrm{kDa}$ type IV collagenase gene expression which is associated with invasiveness of tumor cells. Oncogene 1993;8:395-405

Sehgal I, Thompson TC. Novel regulation of type IV collagenase (matrix metalloproteinase-9 and -2) activities by transforming growth factor-beta1 in human prostate cancer cell lines. Mol Biol Cell 1999;10:407-16

Shih SC, Mullen A, Abrams K, Mukhopadhyay D, Claffey KP. Role of protein kinase $C$ isoforms in phorbol ester-induced vascular endothelial growth factor expression in human glioblastoma cells. J Biol Chem 1999;274:15407-14

Simon C, Goepfert H, Boyd D. Inhibition of the p38 mitogenactivated protein kinase by SB 203580 blocks PMA-induced Mr 92,000 type IV collagenase secretion and in vitro invasion. Cancer Res 1998;58:1135-9

Vignola AM, Riccobono L, Mirabella A, Profita M, Chanez P, Bellia V, Mautino G, D'Accardi P, Bousquet J, Bonsignore G. Sputum metalloproteinase-9/tissue inhibitor of metalloproteinase-1 ratio correlates with airflow obstruction in asthma and chronic bronchitis. Am J Respir Crit Care Med 1998;158: 
$1945-50$

Visse R, Nagase H. Matrix metalloproteinases and tissue inhibitors of metalloproteinases: structure, function, and biochemistry. Circ Res 2003;92:827-39

Vliagoftis $H$, Schwingshackl A, Milne CD, Duszyk M, Hollenberg MD, Wallace JL, Befus AD, Moqbel R. Proteinaseactivated receptor-2-mediated matrix metalloproteinase-9 release from airway epithelial cells. J Allergy Clin Immunol 2000; $106: 537-45$

Woo CH, Lim JH, Kim JH. Lipopolysaccharide induces matrix metalloproteinase-9 expression via a mitochondrial reactive oxygen species-p38 kinase-activator protein-1 pathway in Raw 264.7 cells. J Immunol 2004;173:6973-80

Wu CY, Hsieh HL, Jou MJ, Yang CM. Involvement of p42/p44 MAPK, p38 MAPK, JNK and nuclear factor-kappa B in inter- leukin-1 beta-induced matrix metalloproteinase-9 expression in rat brain astrocytes. J Neurochem 2004;90:1477-88

Xie B, Laouar A, Huberman E. Fibronectin-mediated cell adhesion is required for induction of $92-\mathrm{kDa}$ type IV collagenase/gelatinase (MMP-9) gene expression during macrophage differentiation. The signaling role of protein kinase C-beta. J Biol Chem 1998;273:11576-82

Yaney GC, Fairbanks JM, Deeney JT, Korchak HM, Tornheim $\mathrm{K}$, Corkey BE. Potentiation of insulin secretion by phorbol esters is mediated by PKC-alpha and $\mathrm{nPKC}$ isoforms. Am J Physiol Endocrinol Metab 2002;283:E880-8

Yoo MH, Woo CH, You HJ, Cho SH, Kim BC, Choi JE, Chun JS, Jhun BH, Kim TS, Kim JH. Role of the cytosolic phospholipase A2-linked cascade in signaling by an oncogenic, constitutively active Ha-Ras isoform. J Biol Chem 2001;276: 24645-53 